\title{
SOSIALISASI WAWASAN PLAGIARISME KARYA TULIS ILMIAH UNTUK MAHASISWA SELAMA PERKULIAHAN ONLINE DI MASA PANDEMI
}

\author{
Itsna Oktaviyanti'1), Umar ${ }^{1)}$, Muhammad Erfan ${ }^{1)}$, Setiani Novitasari'1), Mohammad Archi Maulyda') \\ 1)Program Studi Pendidikan Guru Sekolah Dasar, FKIP, Universitas Mataram, Mataram, Indonesia \\ Corresponding author : Itsna Oktaviyanti \\ E-mail : itsna@unram.ac.id
}

\section{Diterima 13 Oktober 2021, Direvisi 26 November 2021, Disetujui 26 November 2021}

\begin{abstract}
ABSTRAK
Dalam dunia akademisi plagiarisme merupakan suatu perbuatan tidak terpuji karena merupakan tindakan mencuri ide atau gagasan orang lain. Namun demikian, tindakan plagiarisme masih sering dilakukan mahasiswa dalam menulis karya tulis ilmiah. Untuk mengatasi persoalan itu maka dilakukan sosialisasi wawasan plagiarisme karya tulis ilmiah sebagai bentuk kegiatan pengabdian masyarakat yang ditujukan kepada mahasiswa PGSD. Kegiatan ini bertujuan untuk memberi pemahaman yang baik kepada mahasiswa tentang definisi plagiarisme, ruang lingkup plagiarisme, faktor penyebab plagiarisme, tipe plagiarisme dan sanksinya, cara menghindari plagiarisme, simulasi cek plagiarisme dan teknik parafrasa. Metode Pelaksanaan sosialisasi kegiatan dilakukan secara daring (online) melalui media zoom meeting. Dari hasil pre test dan post test menunjukan bahwa terdapat peningkatan yang signifikan pemahaman mahasiswa tentang plagiarisme. Wawasan tentang plagiarisme sangat penting dalam menunjang keberhasilan mahasiswa dalam menulis karya ilmiah yang bebas plagiat.
\end{abstract}

Kata kunci: wawasan plagiarisme; karya tulis ilmiah

\begin{abstract}
In the academic world, plagiarism is an act that is not commendable because it is an act of stealing other people's ideas or ideas. However, plagiarism is still often done by students in writing scientific papers. To overcome this problem, socialization of plagiarism insights into scientific writings was carried out as a form of community service activity aimed at PGSD students. This activity aims to give students a good understanding of the definition of plagiarism, the scope of plagiarism, the causes of plagiarism, the types of plagiarism and its sanctions, how to avoid plagiarism, simulation of plagiarism checks and paraphrasing techniques. Methods of the socialization of activities is carried out online through zoom meeting. The results of the pre test and post test showed that there was a significant increase in students' understanding of plagiarism. Insight about plagiarism is very important in supporting the success of students in writing plagiarism-free scientific papers.
\end{abstract}

Keywords: plagiarism insight;scientific writing

\section{PENDAHULUAN}

Situasi pandemi di Indonesia sudah berjalan hampir 1 tahun. Pandemi yang tercatat mulai melanda Indonesia semenjak bulan Maret 2020 ini masih belum menunjukkan tandatanda berakhir. Berdasarkan data yang dipaparkan Hadi (2020) grafik jumlah pasien positif COVID yang tercatat masih belum menunjukkan grafik penurunan. Meskipun vaksin COVID-19 saat ini sudah mulai ditemukan dan didistribusikan, namun situasi pandemic ini masih belum bisa diakhiri dalam waktu dekat (Wu \& McGoogan, 2020). Bahkan Shoenfeld (2020) memprediksi bahwa situasi pandemic masih akan bertahan selama tahun 2021. Dengan demikian, kondisi pandemi ini akan mempengaruhi beberapa aspek-aspek penting dalam keberlangsungan roda kehidupan manusia.

Selain masalah ekonomi, salah satu aspek penting yeng terdampak situasi pandemi COVID-19 ini adalah aspek Pendidikan (Gunawan et al., 2020). Selama pandemi, proses pembelajaran di kelas dilaksanakan tidak secara tatap muka. Mengingat salah satu cara memutus rantai penularan COVID-19 adalah dengan menjaga jarak, maka proses belajar tatap muka di kelas dirasa dapat menyebabkan penularan virus ini semakin merajalela (Maulyda et al., 2020). Maka dari itu, berdasarkan surat edaran Kemendikbud No.4 Tahun 2020 bahwa proses kegiatan belajar mengajar (KBM) harus dilaksanakan secara online. 
Terutama pada jenjang perguruan tinggi, bahkan sebelum pandemi COVID-19 pemerintah sudah mencanangkan platform pembelajaran online seperti SPADA. Di Universitas Mataram sendiri, platform pembelajaran berbasis moodle ini telah digunakan semenjak tahun 2018. Pada tahun 2020, penggunaan SPADA ini lebih dioptimalkan oleh Universitas Mataram mengingat proses perkuliahan wajib dilaksanakan secara daring (online). Selain berisi panduan, modul, platform virtual meeting, forum diskusi, dan quiz, platform SPADA juga memuat tools untuk mengupload tugas-tugas pada setiap pertemuanya. Selain menggunakan platform ini, tidak sedikit dosen yang menggunakan Whatsapp Group sebagai tempat untuk melaksanakan perkuliahan.

Selama perkuliahan daring (online) rata-rata dosen menggunakan metode penugasan dalam proses KBM. Penugasan ini dirasa cara yang paling mudah dan efektif untuk mengisi proses pekuliahan selama daring, dengan asusmsi mahasiswa sudah cukup dewasa untuk belajar secara mandiri dengan rambu-rambu (tugas) dari dosen (Liu, 2019). Mesikpun demikian, metode ini juga memiliki banyak kelemahan, seperti informasi tentang aktifitas mahasiswa (Casey \& Hallissy, 2016). Sebagai dosen, metode penugasan mandiri akan membuat penilaian dosen hanya fokus pada hasil tugas yang diberikan. Proses pengerjaan tugas dan seluruh aktifitas pengerjaan tugas tidak dapat dinilai oleh dosen, karena dosen tidak memiliki informasi terkait hal tersebut. Tidak adanya pengawasan dalam metode penugasan mandiri juga menyebabkan banyak mahasiswa memanfaatkan hal tersebut untuk melakukan perilaku kecurangan seperti plagiarisme. Jenis tugas mandiri yang sering diberikan oleh dosen adalah pembuatan makalah atau karya tulis ilmiah. Pembuatan karya tulis ilimiah ini dapat melatih mahasiswa dalam menganalisa topik dan membahasnya sesuai dengan pemahaman yang dimiliki (Melfianora, 2019). Salah satu manfaat lain dari pemberian tugas karya tulis ilmiah adalah dapat melatih mahasiswa dalam menyelesaikan tugas akhir atau skripsi nantinya. Karena itu, kebanyakan dosen akan memberikan tugas membuat karya tulis ilmiah untuk dipresentasikan sehingga pemahaman mahasiswa lebih kuat karena didapat dengan penggalian mandiri dengan bimbingan dosen (Studen-Centered). Meskipun demikian, pemberian tugas membuat karya tulis ilmiah selama perkuliahan online juga tidak memiliki kelemahan.

Tidak adanya pengawasan dari dosen, menyebabkan adanya kecenderungan mahasiswa melakukan kegiatan plagiarisme karya tulis orang lain. Bila melihat perkembangan platform pencarian elektronik seperti Google, Bing, atau Browser-browser lainya, kita tentu memahami bahwa platformplatform ini telah menyediakan berbagai macam informasi dan data yang kita butuhkan (Rahardja et al., 2016). Namun apabila kita tidak "dewasa" dalam menggunakanya, maka kita akan terjerumus dalam perilaku-perilaku yang salah seperti halnya plagiarisme. Mahasiswa tentu akan dimudahkan dengan mencari informasi dan data sesuai topik yang dibutuhkan dalam platform ini. Namun, kemudahan mencari informasi ini juga bisa memperbesar kemungkinan mahasiswa tidak melakukan prosedur pengutipan yang sesuai dengan kode etik, namun asal copy paste saja. Apabila mahasiswa sudah terbiasa melakukan plagiarisme, maka akan muncul kekawatiran kebiasaan ini akan terus dibawa hingga mereka mengerjakan skripsi atau bahkan ketika mereka sudah berada pada dunia kerja (Boger \& Eng, 2010). Hal ini tentu sangat berbahaya, karena kemungkinan mahasiswa akan berpikir bahwa kegiatan plagiarisme ini adalah suatu hal yang wajar dan boleh dilakukan. Berdasarkan hal tersebut, tim pengabdian melihat adanya masalah ketidak tahuan mahasiswa terkait dengan kode etik publikasi karya tulis ilmiah. Perlu adanya pemberian wawasan kepada mahasiswa terkait rambu-rambu penulisan karya tulis ilmiah terutama dalam menyadur ide/gagasan milik orang lain. Berdasarkan hasil studi pendahuluan yang dilakukan oleh tim pengabdian PGSD, masih banyak mahasiswa yang melakukan praktik copy paste untuk menyelesaikan penulisan karya tulis ilmiah yang ditugaskan oleh dosen selama perkuliahan daring. Untuk menyelesaikan permasalahan ini, salah satu upaya yang dapat dilakukan adalah dengan mengadakan sosialisasi terkait kode etik penulisan karya ilmiah terutama pada masalah plagiarisme kepada mahasiswa.

Plagiarisme terkadang dipilih sebagai jalan pintas untuk menyelesaikan tuntutan sebuah karya tulis ilmiah. Mahasiswa prodi PGSD tentu juga dituntut untuk membuat karya tulis ilmiah sebagai pemenuhan tugas pada suatu mata kuliah. Tindakan plagiarisme akan menurunkan kemampuan mahasiswa untuk menyelesaikan masalah, berpikir kritis dan tentu kreativitas mahasiswa juga akan menurun. Mahasiswa yang melakukan copy paste sama saja mencuri ide orang lain dan tidak menyelesaikan masalahnya sendiri. Artinya klaim karya tulis ilmiah yang diberikan kepada dosen merupakan salah satu bentuk 
pelanggaran kode etik dalam penulisan karya tulis ilmiah. Sehingga praktik plagiarisme dikalangan mahasiswa ini harus dapat diminimalisir dan jika bisa dihilangkan.

Sosialisasi wawasan plagirasisme karya tulis ilmiah untuk mahasiswa program studi PGSD akan dilakukan secara daring (virtual meeting). Hal ini dilakukan dalam rangka menjaga protokol Kesehatan COVID-19, dan mematuhi surat edaran yang sudah diberikan oleh Universitas Mataram, terkait kegiatan perkuliahan selama pandemi. Sasaran dari kegiatan ini adalah mahasiswa program studi PGSD di semua semester yang akan melaksanakan perkuliahan secara online pada semester Genap 2020/2021. Setelah dilakukannya kegiatan ini diharapkan mahasiswa program studi PGSD dapat berkomitmen untuk tidak melakukan tindakan plagiarisme dalam menyelesaikan sebuah karya tulis ilmiah.

\section{METODE}

Kegiatan sosialisasi dilakukan secara daring (online) melalui zoom meeting pada Hari Ahad, Tanggal 8 Agustus 2021. Mitra yang dilibatkan adalah mitra internal yaitu Program Studi Pendidikan Guru Sekolah Dasar Fakultas Keguruan dan IImu Pendidikan Universitas Mataram dengan peserta yang ditargetkan adalah 400 orang mahasiswa mahasiswi semester akhir.

Dalam melaksanakan kegiatan pengabdian ini, tim telah merancang beberapa tahapan kegiatan yang sesuai dengan tujuan pengabdian dilakukan. Adapaun tahapanya terdiri dari Kooridnasi, Promosi, Sosialisasi, dan Evaluasi yang dijelaskan pada sub bab selanjutnya sebagai berikut:

\begin{tabular}{|c|c|}
\hline $\begin{array}{l}\text { Tahap } \\
\text { Sosialisasi }\end{array}$ & $\begin{array}{l}\text { Tahap Evaluasi } \\
\text { dan Pelaporan }\end{array}$ \\
\hline $\begin{array}{l}\text {-Sosialisasi } \\
\text { masalah } \\
\text { plagiarisme } \\
\text { penulisan karya } \\
\text { tulis ilmiah } \\
\text { yang dilakukan } \\
\text { oleh } \\
\text { mahasiswa. }\end{array}$ & $\begin{array}{l}\text { - Meningkatnya } \\
\text { wawasan } \\
\text { plagiarisme } \\
\text { penulisan kaya } \\
\text { tulis ilmiah } \\
\text { lewat } \\
\text { googleform. } \\
\text { - Penyusunan } \\
\text { Laporan } \\
\text { Pengabdian } \\
\text { kepada } \\
\text { Masyarakat } \\
\text { - Publikasi } \\
\text { Luaran }\end{array}$ \\
\hline
\end{tabular}

Gambar 1. Tahapan Pelaksanaan Kegiatan Pengabdian kepada Masyarakat

\section{a. Koordinasi}

Sebelum melaksanakan kegiatan pengabdian, tim terlebih dulu melakukan koordinasi untuk menentukan jobdesk masingmasing anggota. Pada tahap koordinasi ini, tim juga memetakan masalah-masalah kunci dan solusi strategis untuk menyelesaiakan permasalahan tersebut. Setelah itu tim juga berkoordinasi dengan Ketua Program Studi Pendidikan Guru Sekolah Dasar, untuk mendapatkan masukan-masukan agar kegiatan pengabdian yang dilaksanakan dapat berdampak maksimal dan sesuai sasaran. Koordinasi selanjutnya dilakukan oleh tim melalui Whatsapp Group secara online, untuk membahas dan mematangkan konsep kegiatan sosialisasi yang akan dilaksanakan seperti waktu, durasi, dan materi yang akan disampaikan saat sosialisasi.

\section{b. Promosi}

Tahap selanjutnya adalah pembautan brosur, dan penjaringan peserta. Penjaringan peserta dilakukan melalui grup-grup masingmasing kelas pada tiap Angkatan. Selain itu brosur juga dipublish pada sosial media masing-masing tim anggota pengabdian untuk menambah jangkauan peserta. Setiap peserta yang berminat akan menscan barcode yang akan langsung terkoneksi pada Whatsapp Group peserta sosialisasi kegiatan ini. Sehingga untuk koordinasi dengan peserta seperti terkait, link Zoom, presensi kehadiran, atau masalah-masalah lain dapat dilakukan secara efektif.

\section{c. Pelaksanaan Kegiatan}

Kegiatan sosialisasi dilaksanakan pada hari minggu via Zoom Meeting. Kegiatan dilaksanakan dengan durasi 2 jam mulai dari pukul 09.00 Wita - 11.00 Wita. Kegiatan 
dilaksanakan secara online mengingat kondisi Pandemi COVID-19 yang masih mengancam di wilayah Kota Mataram Nusa Tenggara Barat.

\section{d. Evaluasi Kegiatan}

Tahap evaluasi dan pelaporan merupakan tahap akhir dari kegiatan dan dilakukan guna mengukur tingkat ketercapaian tujuan pengabdian kepada masyarakat dan penyusunan laporan tentang pelaksanaan kegiatan secara keseluruhan. Instrumen pengukur keberhasilan kegiatan adalah soal pretest dan postest yang akan diberikan kepada peserta sebelum dan sesudah pemberian materi oleh narasumber. Selain itu peserta juga diberikan angket respon terhadap sosialisasi yang telah dilaksanakan. Hal ini dilakukan untuk melihat kehandalan narasumber dalam memberikan materi.

\section{HASIL DAN PEMBAHASAN}

\section{a. Koordinasi}

Rapat koordinasi dilakukan untuk membicarakan pembagian materi dan segala hal yang berkaitan dengan logistik kegiatan sosialisasi. Koordinasi pertama dilaksanakan pada hari Senin, 26 juli 2021. Rapat koordinasi dilaksanakan via Whatsapp Group, hal ini dilakukan mengingat kondisi pandemi yang tidak mendukung untuk dilakukakanya rapat koordinasi secara langsung. Pada rapat koordinasi ini juga lah, diputuskan bahwa kegiatan sosialisasi akan dilaksanakan pada hari Minggu, 8 Agustus 2021. Koordinasi selanjutnya adalah memutuskan rundown acara terakhir dan sekaligus melakukan gladi bersih untuk kegiatan sosialisasi.

\section{b. Promosi}

Setelah rapat koordinasi pertama dilaksanakan, langkah selanjutnya adalah menyiapkan poster kegiatan sosialisasi. Poster ini dibuat untuk mempermudah proses penyebaran informasi kegiatan yang akan dilaksanakan. Pada poster ini juga diberikan barcode link grup Whatsapp peserta agar lebih memperbudah peserta yang ingin mengikuti kegiatan untuk bergabung. Adapun desain poster yang dibuat adalah sebagai berikut:

Penyebaran poster dilaksanakan via Whatsapp Group kelas-kelas mahasiswa PGSD, FKIP, Universitas Mataram. Sasaran utama dalam kegaitan sosialisasi ini adalah mahasiswa semester 7 yang akan mempersiapkan diri untuk memulai menulis skripsi. Meskipun demikian, jika ada mahasiswa semester awal yang ingin mengikuti kegiatan tetap diperbolehkan.

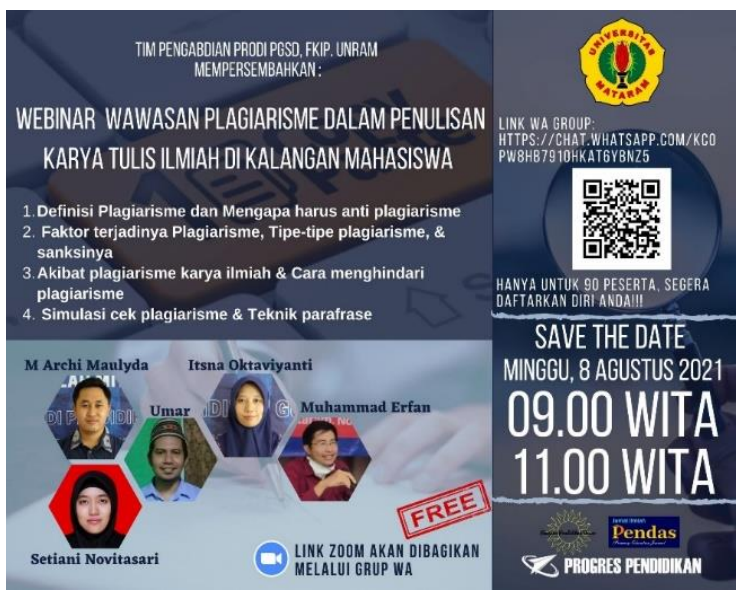

Gambar 2. Poster Kegiatan

Setelah dilaksanakan penyebaran poster ini, mulai bergabung 71 mahasiswa PGSD kedalam grup peserta yang sudah disediakan sebelumnya. Adapaun komposisi jumlah mahasiswa berdasarkan semester adalah sebagai berikut:

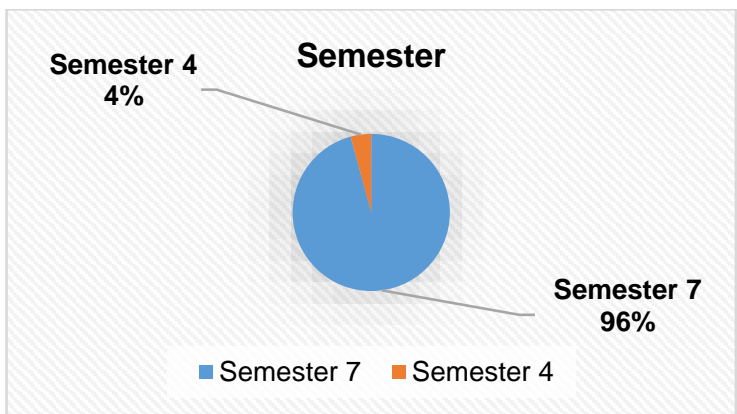

Gambar 3. Karakteristik peserta kegiatan

\section{c. Pelaksanaan Kegiatan}

Pelaksanakan dilaksanakan sesuai dengan rencana, yakni pada hari Minggu, 8 Agustus 2021. Kegiatan dilaksanakan via Zoom Meeting, dimana link Zoom (https://zoom.us///9973999891 ?pwd=RnF2RX R6K3Q2a1lpMkswbUluOVJqdz09) dibagikan kepada grup peserta yang telah diberikan sebelumnya. Pembagian link Zoom juga diberikan pada hari Minggu, 8 Agustus 2021. Kegiatan dimulai tepat waktu yakni pukul 09.00 Wita. Kegiatan dimulai dengan pembukaan oleh Setiani Novitasari, S. Pd., M. Pd., selaku MC kegiatan sekaligus memimpin doa sebelum kegiatan dimulai. 


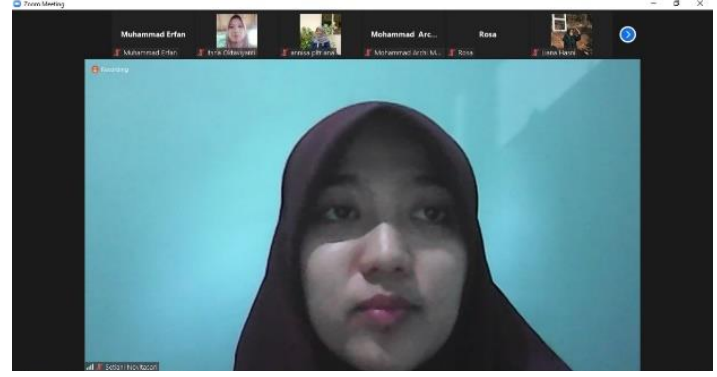

Gambar 4. Pembukaan kegiatan oleh MC

Kegiatan selanjutnya adalah pengisian soal pretest melalui link: https://bit.ly/PrePost Web-Plagiarisme yang dibagikan lewat chat Zoom dan Whatsapp Group. Waktu pengisian soal pretest adalah 10 menit. Setelah pretest, kegiatan langsung dilanjutkan pada pemaparan materi pertama berkaitan dengan "Definisi Plagiarisme dan Mengapa haru anti plagiarisme?" yang dipaparkan oleh Itsna Oktaviyanti, S. Pd., M. $P d$., sebagai narasumber.

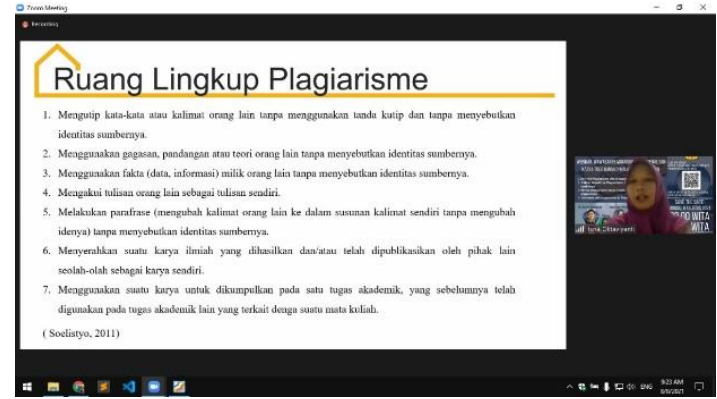

Gambar 5. Dokumentasi Narasumber Pertama

Setelah selesai, kegiatan dilanjutkan dengan pemberian narasumber kedua, ketiga dan keempat, dimana masing-masing narasumber mendapatkan waktu 15 menit untuk melakukan presentasi.

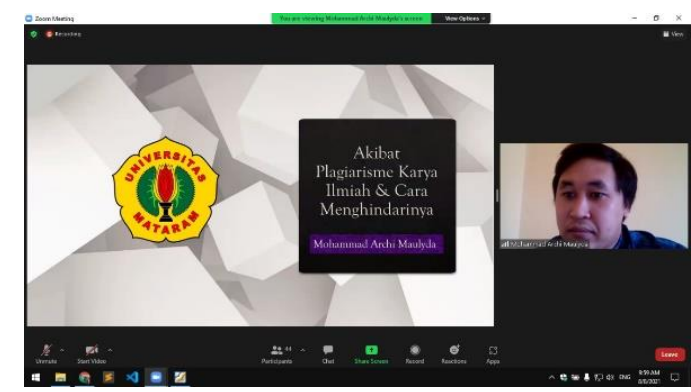

Gambar 6. Dokumentasi Narasumber Kedua

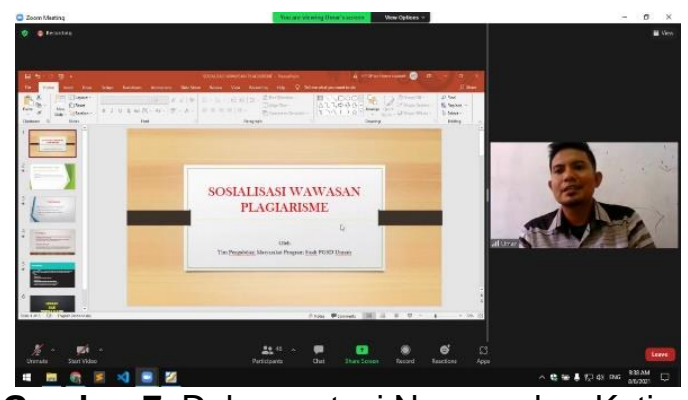

Gambar 7. Dokumentasi Narasumber Ketiga

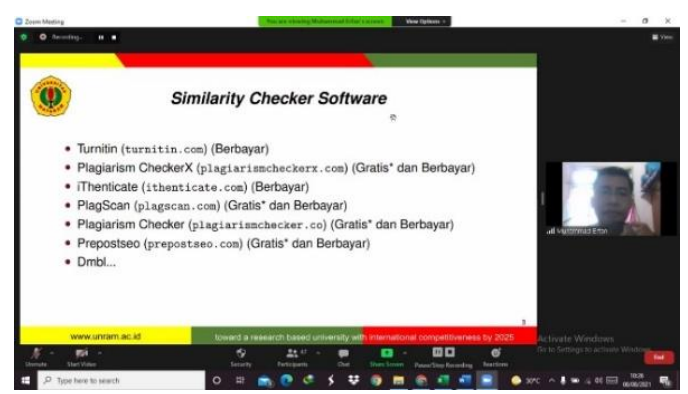

Gambar 8. Dokumentasi Narasumber Keempat

Kegiatan presentasi berjalan dengan lancar dan tidak ada kendala jaringan yang dialami oleh narasumber. Proses transisi antar pemateri diatur oleh MC yang sekaligus menjadi moderator. Secara keseluruhan, proses penyampaian materi dilaksanakan selama 1 jam 20 menit, karena untuk pemateri pertama dan pemateri ketiga, narasumber membutuhkan waktu lebih dari 15 menit untuk menyelesaikan presentasinya. Setelah semua narasumber menyampaikan materi, peserta dipersilahkan untuk bertanya pada sesi diskusi. Proses diskusi dan tanya-jawab berjalan dengan baik serta aktif. Setelah diskusi tanyatanya jawab sudah selesai dilakukan, peserta kembali diminta untuk mengisi soal postest dan angket respon peserta. Pengisian soal postest dan angket respon peserta ini adalah 15 menit.

\section{d. Evaluasi Kegiatan}

Untuk mengukur keberhasilan kegiatan, tim menggunakan instrument soal pre-post dan angket respon peserta. Hasil nilai pre-post kegiatan dapat dilihat dari Tabel 1 berikut:

Tabel 1. Hasil pre-post peserta

\begin{tabular}{ccc}
\hline Rentang Skor & Pretest & Postest \\
\hline $0-20$ & 17 & 2 \\
$21-40$ & 46 & 24 \\
$41-60$ & 7 & 37 \\
$61-80$ & 1 & 6 \\
$81-100$ & 0 & 2 \\
\hline
\end{tabular}

Tabel 1 di atas menunjukkan adanya kenaikan wawasan plagiarisme yang dimiliki 
oleh peserta. Jumlah peserta yang mendapatkan skor 0-20 turun dari 17 menjadi hanya 2 peserta. Peserta yang mendapatkan skor 21-40 juga mengalami penurunan signifikan. Dari 46 menjadi 24 peserta. Sedangkan skor 41-60 merupakan rentang skor yang paling banyak dimiliki peserta dengan jumlah 37 peserta. Skor ini naik dari yang sebelumnya hanya 7 peserta yang mendapat skor pada rentang ini. Untuk rentang skor 61-80, terjadi kenaikan jumlah peserta dari 1 peserta menjadi 6 peserta. Rentang skor terakhir dan sekaligus tertinggi adalah 81-100 dimana sebelumnya tidak ada peserta yang mendapat skor pada rentang ini, namun pada hasil postest terdapat 2 peserta yang dapat skor pada rentang ini. Secara umum, berdasarkan hasil pre-post ini dapat dikatakan bahwa kegiatan yang dilaksanakan berhasil.

Sedangkan berdasarkan hasil angket respon peserta, didapatkan data sebagai berikut:

- Tidak Baik - Kurang Baik - Baik - Sangat Baik

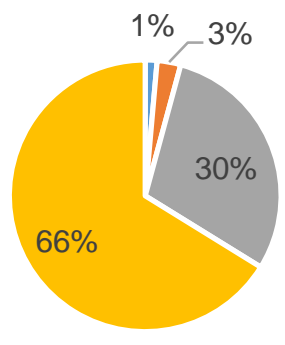

Gambar 9. Kemampuan narasumber dalam menyampaikan materi

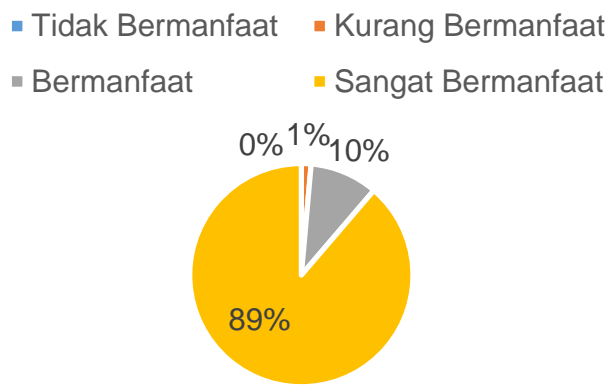

Gambar 10. Kebermanfaatan kegiatan untuk peserta

Berdasarkan hasil angket respon peserta, dapat dilihat bahwa $66 \%$ peserta menyatakan bahwa narasumber sudah menyampaikan materi dengan sangat baik. Sedangkan 30\% peserta memilih baik. Meskipun demikian tetap ada 3\% peserta yang menyatakan bahwa penyampaian materi oleh narasumber kurang baik, sedangkan $1 \%$ nya menyatakan sangat tidak baik. Hal ini tentu perlu menjadi bahan perbaikan dan refleksi diri untuk para narasumber bila melaksanakan kegiatan serupa kedepanya. Sedangkan dari sudut pandang kebermanfaatan, $89 \%$ peserta menyatakan bahwa kegiatan yang dilaksanakan sangat bermanfaat. Sepuluh persen diantaranya menyatakan bermanfaat, sedangkan $1 \%$ nya mnyatakan kurang bermanfaat. Tidak ada satupun peserta yang menyatakan bahwa kegiatan ini tidak bermanfaat. Dengan demikian, dapat disimpukan bahwa kegiatan sosialisasi yang dilaksanakan mendapat respon positif dari para peserta.

\section{SIMPULAN DAN SARAN}

Berdasarkan hasil kegiatan sosialisasi yang dilaksanakan, dapat disimpulkan bahwa kegiatan sosialisasi wawasan plagiarisme karya tulis ilmiah yang telah dilaksanakan berjalan dengan baik dan lancar. Berdasarkan hasil pre-post peserta menunjukkan bahwa kegiatan yang dilakukan berhasil, karena dapat meningkatkan skor wawasan plagiarisme yang dimiliki oleh peserta. Selain itu, dari hasil angket respon peserta menunjukkan bahwa kegiatan yang dilaksanakan dapat diterima secara baik oleh peserta. Peserta juga menyatakan bahwa kegiatan yang dilaksanakan sangat bermanfaat untuk peserta.

\section{UCAPAN TERIMA KASIH}

Penulis mengucapkan terima kasih kepada Universitas Mataram yang telah mendukung secara penuh kegiatan sosialisasi secara finansial lewat skema PNBP Tahun Anggaran 2021.

\section{DAFTAR RUJUKAN}

Boger, T. S., \& Eng, A.-L. (2010). Student perspective on plagiarism. Nordic Journal of Information Literacy in Higher Education, 3(1). https://doi.org/10.15845/noril.v3i1.130

Casey, L., \& Hallissy, M. (2016). Live Learning: Online Teaching, Digital Literacy and the Practice of Inquiry. Irish Journal of Technology Enhanced Learning, 1(1). https://doi.org/10.22554/ijtel.v1i1.4

Gunawan, G., Suranti, N. M. Y., \& Fathoroni, F. (2020). Variations of Models and Learning Platforms for Prospective Teachers During the COVID-19 Pandemic Period. Indonesian Journal of Teacher Education, 1(2), 61-70. https://journal.publicationcenter.com/index.php/ijte/article/view/9 5

Liu, Y. (2019). Using reflections and questioning 
to engage and challenge online graduate learners in education. Research and Practice in Technology Enhanced Learning, 14(1), 3. https://doi.org/10.1186/s41039-0190098-z

Maulyda, M. A., Budiharjo, A., Erfan, M., \& Radha, R. (2020). Level Berpikir Metakognisi Mahasiswa Selama Perkuliahan Online di Masa Pandemi. Jurnal Pembelajaran Matematika Inovatif, 3(6), 679-690. https://doi.org/10.22460/jpmi.v3i6.679690

Melfianora, M. (2019). Penulisan Karya Tulis IImiah Dengan Studi Literatur. Open Science Framework, 12(1), 14-26.

Rahardja, U., Tiara, K., \& Rosalinda, I. A. (2016). Pemanfaatan Google Scholar Dan Citation Dalam Memenuhi Kebutuhan Pembuatan Skripsi Mahasiswa Pada Perguruan Tinggi. Technomedia Journal, 1(1), 95-113. https://doi.org/10.33050/tmj.v1i1.28

Shoenfeld, Y. (2020). Corona (COVID-19) time musings: Our involvement in COVID-19 pathogenesis, diagnosis, treatment and vaccine planning. Autoimmunity Reviews, $\quad 19(6), 102538$. https://doi.org/10.1016/j.autrev.2020.1 02538

Wu, Z., \& McGoogan, J. M. (2020). Characteristics of and Important Lessons From the Coronavirus Disease 2019 (COVID-19) Outbreak in China. JAMA, $\quad 323(13), \quad 1239$. https://doi.org/10.1001/jama.2020.264 8 